\title{
Factors affecting farmers' participation in watershed management programs in the Northeastern highlands of Ethiopia: a case study in the Teleyayen sub-watershed
}

\author{
Alem-meta Assefa Agidew ${ }^{1 *}$ and K. N. Singh ${ }^{2}$
}

\begin{abstract}
Introduction: This study investigated factors affecting farmers' participation in watershed management programs in the Northeastern highlands of Ethiopia by taking the Teleyayen sub-watershed as a case study. Data were collected from 215 farm households which were selected from the four villages using a multistage sampling procedure, involving a combination of purposive and random sampling. Data were gathered using a structured survey questionnaire, focus group discussion, and key informant interviews. Descriptive analysis, Pearson correlation analysis, and regression analysis were employed to analyze the data.

Results: Findings of this study showed that farmer's perception has a strong positive correlation $(r=0.612, P=0$. 000) with the farmer's decision to participate in the watershed management programs followed by government support $(r=0.163, P=0.017)$, while the slope of the farmland and the gender of the household head have shown significant and negative associations. The binary logistic regression analysis also revealed that six independent variables were significant in explaining the factors affecting the farmers' decision to participate in watershed management programs. These variables were land redistribution, gender, agricultural labor force, extension service, farm size, and slope. Of these, land redistribution, gender, agricultural labor force, extension service, and slope of the farmland indicated a negative influence, while farm size of a household exerted a positive impact. The study also examined the role of discrete variables in explaining variations of variables in affecting the farmers' decision to participate in the programs. Thus, two variables found to be significant. These variables are the gender of the household head and land tenure security. Accordingly, the chi-square result of the variable $\left(X^{2}=9.052\right)$ of gender was found to be statistically significant at the $95 \%$ level of significance. Similarly, the chi-square result $\left(X^{2}=8.792\right)$ of land tenure security was found to be statistically significant at the $95 \%$ level of significance.
\end{abstract}

Conclusions: The result of the study suggests to work on raising the awareness of farmers' about the long-term benefits of the watershed programs and to design a strategy to diversify their livelihoods.

Keywords: Binary logistic regression model, Ethiopia, Farmers' participation, Watershed management

\footnotetext{
*Correspondence: alexasfaw23@gmail.com

'Department of Geography and Environmental Studies, Wollo University, P.O.

Box 1145, Dessie, Ethiopia

Full list of author information is available at the end of the article
} 


\section{Introduction}

Watersheds around the World are facing serious threats to their water quality and aquatic ecosystems. Moreover, watershed management, which includes water resource utilization control, water pollution control, and economic growth policies, is an effective means of dealing with these issues at the watershed scale (Heathcote 1998). Owing to the complexity of watersheds, uncertainty is one of the key factors influencing watershed management programs. Such uncertainty is manifested by a farmers' reluctance to participate in the watershed management programs. Works of literature reveal that Ethiopian highlands are seriously eroded and becoming unsuitable for cultivation. Watershed management in the Ethiopian highlands therefore urgently needs improvement and conservation of their natural resource for sustainable development and improving food security. Because agriculture is the main sector of the Ethiopian economy and contributes approximately $42 \%$ to the gross domestic product (GDP) and employs over $80 \%$ of the population (MoFED 2010; Diao 2010; ATA (Ethiopian Agricultural Transformation Agency) 2013). Despite its role, agricultural production is constrained by high climate variability where rainfall distribution is extremely uneven both spatially and temporally, and this has negative implications for the livelihoods of people (Georgis et al. 2010). Drought frequently results in crop failure, while high rainfall intensities result in low infiltration and high runoff causing enhanced soil erosion and land degradation. Land degradation in the form of soil erosion and declining land fertility is a serious challenge to agricultural productivity and economic growth (Lemenih 2004). Studies indicate that the Ethiopian highlands have experienced high rates of soil erosion and deforestation, resulting in sediment accumulation in downstream reservoirs and rivers (Haregeweyn et al. 2005; Tamene 2005). High population and livestock density, along with rugged topography and erratic rainfall, exacerbate land degradation. Excess water is also responsible for the soil erosion in the highlands. Recent studies also show that the sediment yields in different rivers range between 180 and $900 \mathrm{t} /$ year per $\mathrm{km}^{2}$ (Rodeco 2002). It is estimated that the trans-boundary Rivers alone carry about 1.3 billion tonnes of sediment each year to neighboring countries (MoWR 1993). Poor watershed management and farming practices have contributed to these rates.

The pressure on the land resource is more severe in the highlands of Ethiopia (> 1500 m.a.s.l), constituting some $45 \%$ of the total area. The highlands accommodate some $88 \%$ of the human and $75 \%$ of the livestock populations and constitute about $95 \%$ of the regularly cultivated lands (FAO 1986). These highlands have indeed been settled for millennia, and agriculture has a matching history. Currently, the highland farming population grows with a rate of around 3\% per annum and correspondingly the livestock population is increasing. These places more demand on more marginal land for cultivation and grazing uses, leading to more de-vegetation and degradation. Hence, introducing watershed management programs in the country becomes mandatory.

Consequently, in Ethiopia watershed management ${ }^{1}$ programs commenced in a formal way in the 1970s. From that time up to the late 1990s, most of the SWC activities were tailored towards reducing soil erosion rather than enhancing agricultural production. These activities lack integration between farm and non-farm measures and were neither effective nor sustainable (Badege 2001; Elias 2002; Melaku 2003). The intervention was more of a top-down approach with the limited participation of beneficiaries. Despite this, the soil and water conservation (SWC) activities had a positive impact on reducing soil erosion and increased land productivity. At the same time, the program has been criticized for prioritizing mechanical measures while ignoring other sustainable land management components, such as conservation land management practices, improved land-use systems and livestock management (Osman and Sauerborn 2001).

In the early 2000s, community-based integrated watershed development was introduced to promote watershed management as a means to achieve broader integrated natural resource management and livelihood improvement objectives within prevailing agro-ecological and socioeconomic environments. Therefore, the SWC activities of the project were developed into a participatory integrated watershed management approach (German et al. 2007) to promote sustainable water and land resources management based on partnerships with the community.

Land degradation is an alarming challenge in the Amhara region where erosion is the main cause of the loss of approximately 2 to 4 billion tonnes of soil annually leaving between 20,000 to 30,000 ha of land unproductive (Taffa 2009). Ambasel and Kutaber districts, where the Teleyayen sub-watershed is located, are among the most degraded districts of the region. These districts have experienced a severe shortage of rainfall, land degradation in the form of soil erosion, and drought occurrence. A number of watershed projects have been implemented in the districts by the government agencies to address the soil erosion and land degradation problems. However, the success rate varies in both space and time due to diverse social and biophysical settings, implying that watershed management programs need a careful analysis of the social and environmental dynamics to successfully address livelihood and conservation concerns.

Therefore, participatory watershed planning and development is a vital necessity in complex landscapes. Interactions between and within communities depend on what happens at different levels of the watershed. Watershed planning has moved away from conventional land-use planning exercise 
to a logical interpretation of the potentials of the land as a function of the needs, demands and aspirations of the people living in the watersheds, including the interactions between people's activities and the land resources. Participatory watershed planning is thus the key to understand what is needed to be done at various levels to sustain, improve, and diversify production while developing and managing the natural resource-base, promote income generation opportunities, increase access to basic services (roads, markets, schools, water, and the like), and make livelihood systems resilient to shocks.

Watershed development project aims at maintaining the product of land in the upstream areas and reduces sedimentation hazards for the downstream reservoirs. Soil and water conservation program within the small watershed management project has been found to be the best development strategies for the rain-fed area. For successful implementation of the watershed program, it is essential to ensure peoples' participation. There are several factors which affect the farmers' participation in the watershed program. Keeping this in view, the study has been undertaken with the objectives to identify personal, physical, and institutional factors affecting farmers' participation in the Teleyayen sub-watershed.

\section{Theoretical framework}

\section{Problems and failures encountered with watershed development}

Watershed development has been problematic when applied in a rigid and conventional manner. This is true when applied without community participation and using only hydrological planning units, where a range of interventions remained limited and post-rehabilitation management aspects were neglected. This resulted in various failures or serious shortcomings difficult to correct. Some examples can be cited in Ethiopia and elsewhere. For instance, the case of the large Borkena dam in South Wollo in the 1980's where the dam was constructed before sufficient conservation measures was in place. Besides, runoff and sedimentation rates were seriously underestimated. It resulted in the filling with silt and coarse materials of the multi-million Birr dam within one rainy season (MoARD (Ministry of Agriculture and Rural Development) 2005). Other examples in Ethiopia include large-scale watershed planning using top-down approaches and rigid technical packages during the 1980 s that resulted in the unsatisfactory performance of several conservation efforts. This shows that a poorly planned watershed approach could result in complete failure. In India, there have been cases of over-exploitation of water-tables resulting from an intensive watershed treatment where some of the major benefits have been reduced, particularly for the poor, because of the competitive use of water resources by richer farmers for irrigation. Other cases of failure included upper ridges planted with monocultures of eucalyptus trees, which depleted water-tables and had a negative ecological effect on soils.

\section{Factors affecting farmers' participation in watershed management programs}

Watershed management has evolved and passed through several developmental stages. In the initial stages, it was a subject of forestry and forestry-related hydrology. The involvement of people was not an issue. It was solely an affair of government forest departments. During the second stage, it became land resources management related, including activities with an eye on economic benefits. At this stage, the focus was on beneficiaries. It is now "participatory and integrated" watershed management, with involvement and contribution from local people. Hence, watershed development is considered an effective approach to raise agricultural productivity, conserve natural resources, and reduce poverty, particularly in the rain-fed regions. However, there are several factors affecting local people's participation in Watershed Development Programs (WDPs). Therefore, a determination of the factors affecting farmers' participation in WDPs is crucial for helping planners, project proponents, and decision makers to ensure that projects are designed to fit local beliefs and values as part of an inclusive democratic process in which ownership is ensured through public participation (Ahmadvand et al. 2011).

A number of studies revealed that some dispositional, demographic, and situational factors are significant in determining farmers' participation in watershed development activities (Faham et al. 2008). Moreover, other studies have shown that participation may depend on an individual characteristic such as age, gender, marital status, household size, and income (Dolisca et al. 2006). Knowledge is an important factor that effects on people participation. People cannot be expected to exhibit positive attitudes towards watersheds if they are unaware of the benefits and cost associated with their participation. Education and information regarding the watershed programs are particularly important. A number of studies had conducted concerning farmers' participation in developmental projects and indicated that highly educated farmers participated to a vaster extent than their lesser educated counterparts (Faham et al. 2008). The general explanation for this relationship is that education exposes people with a broader range of ideas and beliefs and thus encourages a more liberal perspective (McMillan et al. 1996).

An important concern in watershed development is the sharing of the costs of land and water resources development, equitable distribution of the benefits consequent to enhanced crop production. The focus on land development often gave the projects a male-orientation. 
For example, in India, even though government guidelines encouraged greater participation of women in watershed groups, women were often not recognized as members of the watershed committee in their own right; they were viewed as being there to fill the quota required under the guidelines (Seeley et al. 2000). At present, in some parts of India, social customs do not allow active participation and involvement of women in the functioning of committees and village organizations. Watershed development in India is gender insensitive as all the benefits accruing are being cornered exclusively by men (Angurana 2003). Women were generally the losers in watershed development as they lose the access to common lands for grazing of animals and fuel collection (Meinzen-Dick et al. 2004). Women generally paid the cost of development in most watersheds such as plantation programs in the common pool resources.

Previous studies also reported that the influence of age of farmers on their participation in watershed management program is mixed. Hence, some of the researchers, for example, (Khalighi and Ghasemi 2004) found that age had no influence on farmers' participation in watershed management programs; another researcher reported that age is an important variable in explaining farmers' participation (Motevalli 2002; Shahidi 1998). According to Dolisca et al. (2006), household size influences the social level of participation of farmers in participatory programs. A study conducted by Karegar and Abedi Sarvestani (2001) revealed that participation in previous projects stimulates farmer's participation in other projects. According to the study done by Aboueieh (2001), level of participation in extensioneducation classes and the level of contact with extension agents are effective factors on villagers' participation in watershed management programs. The findings of Ebrahim (2000) confirmed that level of awareness of degradation impacts on natural resources is one of the effective factors on the participatory action of people in watershed management projects. A study carried out by Abedini (2001) represented that level of contact with technical experts influence participation. These individual characteristics influence decision-making regarding household behavior, including the decision about whether or not to participate in rural development programs. The participation of farmers is the cornerstone for watershed management programs. The purpose of this study was, therefore, to investigate the rationale of the farmers' decision to participate in watershed management programs taking the Teleyayen sub-watershed as a case study.

\section{Methods}

\section{Description of the study site}

The Teleyayen sub-watershed lies within $11^{\circ} 14^{\prime} 30^{\prime \prime} \mathrm{N}$ and $11^{\circ} 29^{\prime} 30^{\prime \prime} \mathrm{N}$ latitudes and $39^{\circ} 21^{\prime} 0^{\prime \prime} \mathrm{E}$ and $39^{\circ} 33^{\prime}$ $0 " \mathrm{E}$ longitudes. Administratively, it is located in Kutaber and Ambasel districts, South Wollo Zone, Amhara Regional State. The sub-watershed is located about $441 \mathrm{~km}$ North of Addis Ababa (the capital city). It covers a total area of $152 \mathrm{~km}^{2}$. Of this, kutaber shares $125 \mathrm{~km}^{2}(82 \%)$ and Ambasel shares $27 \mathrm{~km}^{2}$ (18\%). The study area is characterized by diverse topographic conditions that form part of the headstream of the Abay (Blue Nile) basin. Its elevation ranges from 1703 to $3406 \mathrm{~m}$ above mean sea level (Fig. 1). A mountainous and highly dissected terrain with steep slopes characterizes most parts of the sub-watershed. The land is a scarce resource in the sub-watershed due to high population pressure and degradation.

The meteorological data used for the study was obtained from Kombolcha Meteorological Station, recorded for Dessie site. Hence, the mean annual temperature of the subwatershed is about $16{ }^{\circ} \mathrm{C}$ and the average annual total rainfall is $1133 \mathrm{~mm}$ (Fig. 2). The sub-watershed rainfall distribution is bimodal received in two rain seasons. More than $58 \%$ of the total rain falls in 2 months of July and August (summer season), while $18 \%$ falls in the spring season (March, April, and May), and less than 5\% of the total occur during the dry months of December, January, and February (winter season). The uneven distribution of the rainfall gives rise to a serious shortage of water during the dry season, particularly in the lower parts of the sub-watershed.

\section{Methods of data collection and sampling technique}

The study used both primary and secondary sources of data. These include household survey questionnaire, focus group discussions (FGDs), field observations, and key informant interviews. Secondary data were also gathered from past studies, reports, books, journals, and internet sources. The household survey questionnaire was conducted to gather data about demographic and socioeconomic characteristics of sample households, institutional services, biophysical characteristics, plot level characteristics, and various sustainable land management (SLM) practices conducted by farmers of the study area. The questions were both closed-ended and openended types. Accordingly, the survey questionnaire was administered between January and February 2016. A formal survey instrument was prepared, and trained enumerators collected the data from the households via personal interviews. This period was chosen mainly to avoid interfering with farmers' peak farming activities. Hence, it is easy to interview the sample farm households and collect the required data. Before full implementation, the structured household questionnaire was pre-tested as a pilot survey in the sample villages. The pilot survey ensures that the present questionnaire is relevant and meaningful to the average respondents, and to decide which questions were relevant for the purpose of the study. Subsequently, on the basis of the feedback obtained from the pre-test, necessary modifications were 


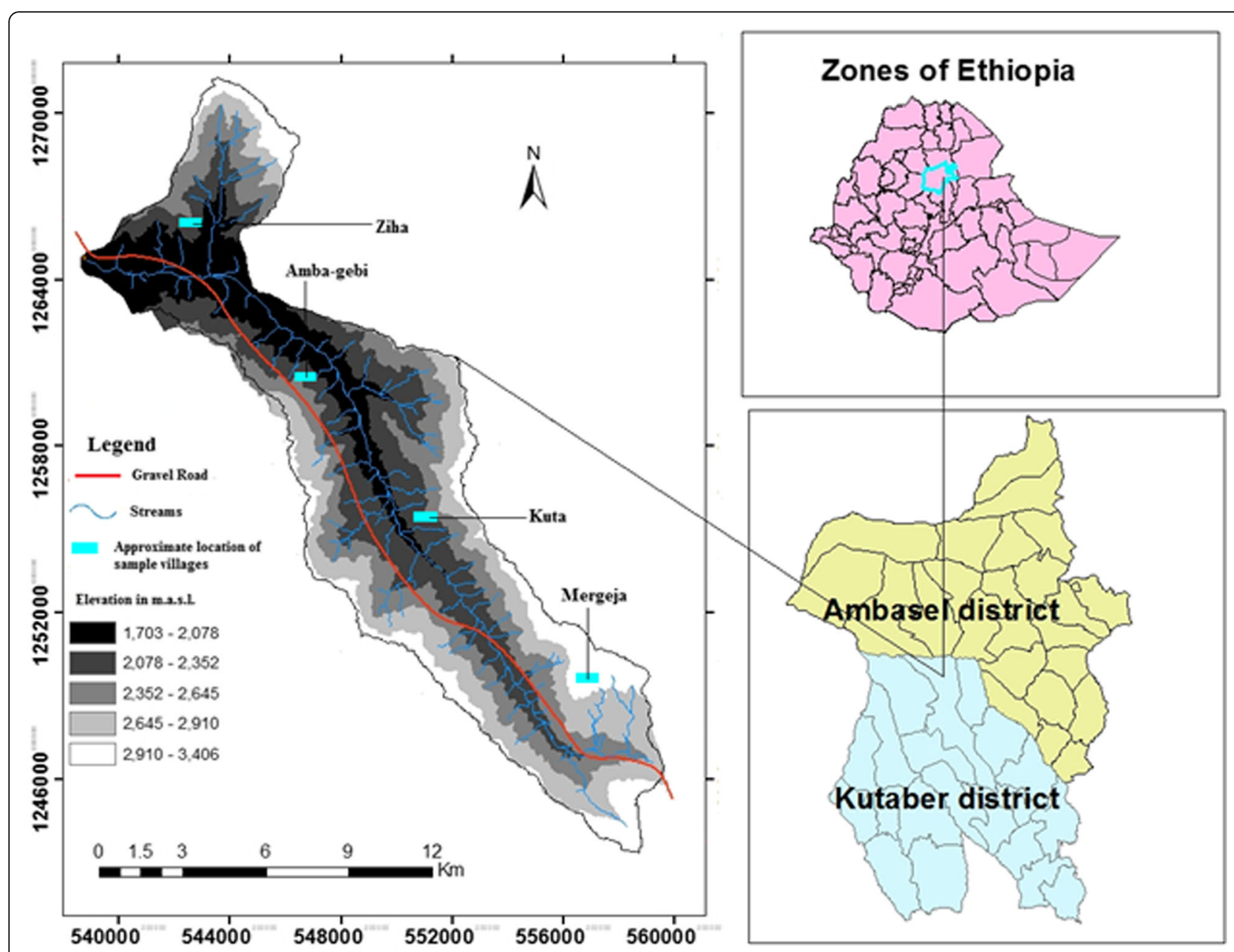

Fig. 1 Location map of the study area

made. Data on the farmers' perception of land degradation, agricultural productivity, and effectiveness of SLM practices were also collected. Field observation was conducted in order to validate information obtained from the farmers through a survey questionnaire. It involves observations of various land degradation features, such as soil erosion and sedimentation, the slope of farmlands, surface runoff and agricultural practices, including the types of crops grown, cropping patterns, and onfarm soil conservation structures.

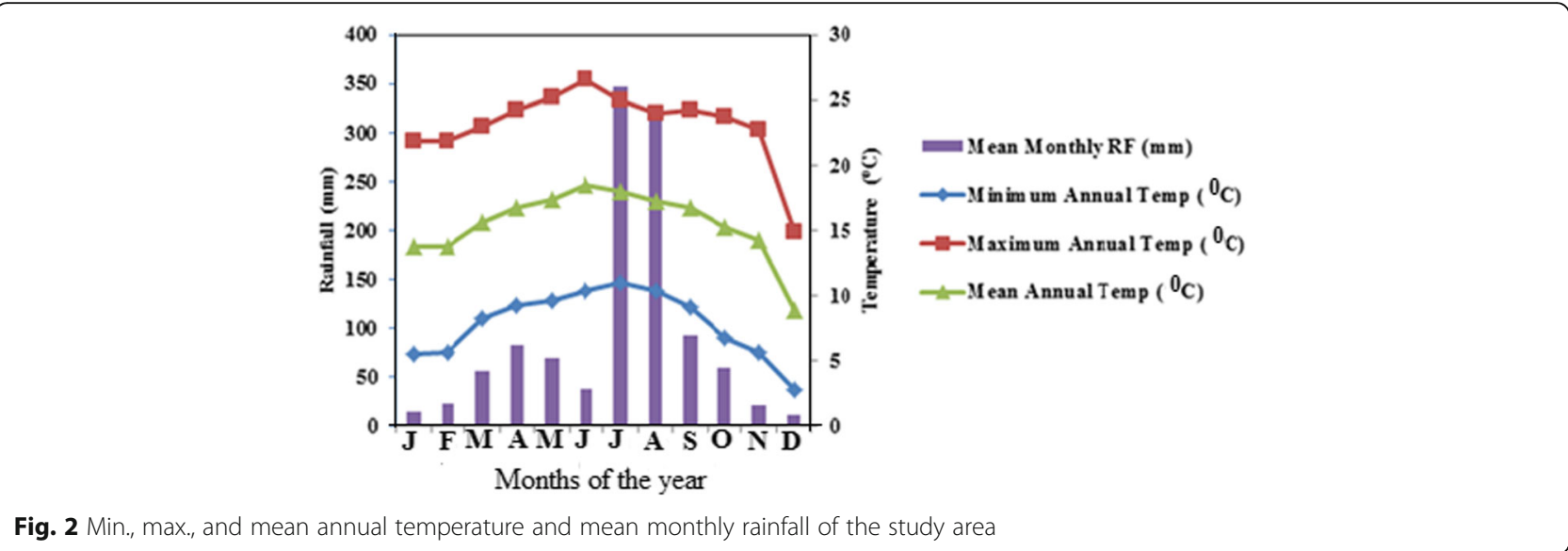


The sample farm household heads were drawn through a multi-stage sampling technique. The sampling technique involves three stages. In the first stage, the names of eight kebeles $^{2}$ (six from Kutaber and two from Ambasel district) were obtained from each respective kebele administrators and then four sample kebeles (three from Kutaber and one from Ambasel district) were selected purposefully. The reason for the selection of these kebeles is based on their agroecological zones and accessibility. In the second stage, four sample villages, one from each sample kebele, were selected randomly. In the third stage, the numbers of all farm households from each selected sample villages were listed. Finally, 172 male-headed and 43 female-headed a total of 215 sample farm households of the study were selected randomly from the four sample villages in a proportional-tosize of each agro-climatic zone (Table 1). These sample farm households were determined using the following formula provided by Yemane (1967) cited in Israel (1992):

$$
n=\frac{N}{1+N(e)^{2}}
$$

where $n$ is the sample size

$N$ is the population size

$e$ is the level of precision (5\%).

Based on the above formula, the total sample households were calculated as follows:

$$
n=465 / 1+465 \times 0.0025=215 \text {. }
$$

\section{Methods of data analysis}

The data of the study were analyzed both quantitatively and qualitatively. The quantitative data were analyzed using various statistical tests based on the level of measurement of the variables involved. Statistical package for social sciences (SPSS-IBM) software, version 21, and Microsoft excel 2010 was used to analyze both inferential and descriptive statistical data. Using descriptive statistics, we compared and contrasted different categories of sample units with respect to the desired characteristics. Hence, in this study, descriptive statistics such as mean, standard deviation, and percentages were used to see the relationships between explanatory variables and the level of farmers' participation in watershed management programs. A binary logistic regression model,
Pearson correlation, and chi-square also used to know the correlation between the dependent and independent variables of the study.

\section{Results and discussion}

Factors affecting farmers' participation in watershed management programs

The dependent variable analyzed in this study was the level of farmers' participation in watershed management programs. Thus, farmers' participation in a watershed management program was measured as a binary dummy variable $(1=$ participated in a watershed management program, 0 = otherwise). The details of explanatory variables used in the analysis are given in Table 2 .

Therefore, a binary logistic regression model was used to investigate factors affecting farmers' participation in the watershed management programs in the Northeastern highlands of Ethiopia. As outlined above, this model was used because of the binary nature of the dependent variable (level of participation). Hence, the logistic model is specified as follows:

$$
\begin{aligned}
\ln (Y)=\ln \left(\frac{Y}{1-Y}\right)= & \beta_{0}+\beta_{1} X_{1}+\beta_{2} X_{2}+\beta_{3} X_{3} \\
& +\ldots \ldots . .+\beta_{n} X_{n}+u_{i}
\end{aligned}
$$

where

$Y=$ The predicted probability of the event (farmers' level of participation in the watershed management programs), which is coded with $1=$ participated; and $0=$ non-participants

$1-Y=$ The predicted probability of the other decision (non-participants of the watershed management programs)

$\beta_{0}=$ Constant

$\beta_{n}=$ Coefficients of explanatory variables

$X_{n}=$ Predictor variables

$u_{i}=$ Error term.

\section{Hypotheses of the study}

In setting our hypotheses, our main interest is to identify factors affecting farmers' participation in watershed

\begin{tabular}{|c|c|c|c|c|c|c|c|c|c|}
\hline \multirow[t]{2}{*}{ District } & \multirow[t]{2}{*}{ Kebele } & \multirow[t]{2}{*}{ Village } & \multicolumn{3}{|c|}{ Total households } & \multicolumn{3}{|c|}{ Sample farm households } & \multirow[t]{2}{*}{ AEZ } \\
\hline & & & Male & Female & Total & Male & Female & Total & \\
\hline Kutaber & Doshign & Mergeja & 19 & 9 & 28 & 1 & 1 & 2 & Moist-wurch \\
\hline Ambasel & Teregma & Ziha & 123 & 28 & 151 & 63 & 14 & 77 & Moist-dega \\
\hline Kutaber & Asecha & Kuta & 81 & 23 & 104 & 44 & 12 & 56 & Moist-dega \\
\hline Kutaber & Amba-Gebi & Amba-gebi & 146 & 36 & 182 & 64 & 16 & 80 & Moist-weyna-dega \\
\hline Total & & & 369 & 96 & 465 & 172 & 43 & 215 & \\
\hline
\end{tabular}
management programs. We present our key hypotheses about the effects of explanatory variables below.

Table 1 Distribution of sample farm households by district and village level 
Table 2 Factors influencing the farmers' decision to participate in watershed management programs

\begin{tabular}{|c|c|c|}
\hline Dependent variable & Description & Unit \\
\hline$Y=L F P$, Level of Farmers participation & $\begin{array}{l}\text { Level of household heads' participation } \\
\text { in a watershed management program }\end{array}$ & 1 if participated, 0 otherwise \\
\hline Independent variables & Description & Unit \\
\hline $\begin{array}{l}X_{1}=\text { OFI, Off-farm income obtained } \\
\text { from non-farm activities }\end{array}$ & Off-farm income & $\begin{array}{l}1 \text { if a household is participated } \\
\text { in off-farm activities, } 0 \text { otherwise }\end{array}$ \\
\hline$X_{2}=\mathrm{LSO}$, Livestock ownership & Households livestock ownership & Number in TLU \\
\hline$X_{3}=L R D$, Periodic land redistribution & Periodic land redistribution & Yes $=1 ; \mathrm{No}=2$ \\
\hline$X_{4}=\mathrm{ES}$, Educational status & Educational status of the household head & $\begin{array}{l}1 \text { if a household head is literate, } \\
0 \text { otherwise }\end{array}$ \\
\hline$X_{5}=\mathrm{LT}$, Land tenure security & Land tenure security of a household & Yes $=1 ; \mathrm{No}=2$ \\
\hline$X_{6}=\mathrm{GHH}$, Gender & Gender of the household head & $\begin{array}{l}1 \text { if a household head is male, } \\
0 \text { otherwise }\end{array}$ \\
\hline$X_{7}=N A L F$, Agricultural labor force & $\begin{array}{l}\text { Number of household members engaged } \\
\text { in agricultural activities }\end{array}$ & Number \\
\hline$X_{8}=$ FS, Farm size & Farm size of the household & Hectare (ha) \\
\hline $\begin{array}{l}X_{9}=\mathrm{EV}, \text { Frequency of extension } \\
\text { visit }\end{array}$ & $\begin{array}{l}\text { Frequency of agricultural extension visits } \\
\text { received }\end{array}$ & $\begin{array}{l}\text { At least four times in a year }=1 \text {; } \\
\text { otherwise }=2\end{array}$ \\
\hline$X_{10}=C S$, Credit service & Access to credit services & Yes $=1 ; \mathrm{No}=2$ \\
\hline $\begin{array}{l}X_{11}=\text { PSNP, productive safety } \\
\text { net program }\end{array}$ & $\begin{array}{l}\text { Household heads' productive safety net } \\
\text { beneficiary }\end{array}$ & $\begin{array}{l}1 \text { if a household head is a PSNP } \\
\text { beneficiary, } 0 \text { otherwise }\end{array}$ \\
\hline$X_{12}=S$, Slope & Slope of the farmland & 1 if the slope is gentle, 0 otherwise \\
\hline
\end{tabular}

\section{Socioeconomic factors}

\section{Educational status of the household head}

Several studies on farmers' participation in developmental projects have reported that highly educated respondents participate to a vaster extent than their lesser educated counterparts (Azizi and Zamani 2009). Therefore, we hypothesized that farmers' participation is positively associated with their decision to participate in watershed management programs.

\section{Gender of the household head}

Gender was measured as a dummy variable with male farmers $=1$ and female farmers $=0$. The gender of $\mathrm{a}$ household head being male is hypothesized to be positive. This is due to the fact that male farmers are well endowed with resources such as land than their female counterparts; therefore, we hypothesized that male farmers' participation is positively associated with their decision to involve in watershed management programs.

\section{The number of agricultural labor force}

Watershed management programs require sufficient agricultural labor force. For example, Bewket (2003) identified a lack of interest in soil and water conservation measures to be explained by a shortage of labor. Thus, household labor is the whole supplier of the required labor for undertaking the farming and soil conservation operation. Accordingly, it is hypothesized that the number of the agricultural labor force is positively correlated with the farmers' decision to participate in watershed management programs.

\section{Off-farm income}

Farmers' involvement in off-farm income-generating activities is expected to help them to support their income. Thus, in this study, it is hypothesized that off-farm income is positively correlated with the farmers' decision to participate in watershed management programs.

\section{Livestock ownership}

Livestock production constitutes a very important component of the agricultural economy of developing countries, a contribution that goes beyond direct food production to include multipurpose uses, such as skins, fiber, fertilizer, and fuel, as well as capital accumulation. Furthermore, livestock is closely linked to the social and cultural lives of several million resource-poor farmers for whom animal ownership ensures varying degrees of sustainable farming and economic stability. Farmers who possess large numbers of livestock are expected to be less interested to participate in watershed management programs than their counterparts. Thus, we hypothesized that livestock ownership is negatively correlated with the farmers' decision to participate in watershed management programs. 


\section{Physical factors \\ Farm size}

Farm size is an important factor to consider when it comes to agricultural production, therefore becoming one of the essential elements of this study. Farmers' with large farm size could decide to participate in watershed management programs to increase their agricultural productivity. According to Zarafshani et al. (2008) and Sharma and Sisodia (2008), land holding size is strongly associated with farmers' participation. Therefore, in this study, it is hypothesized that farm size is positively related to farmers' decision to participate in watershed management programs.

\section{Land tenure security}

For farmers to be able to decide to carry out long-term investment on their farmland, they need the security of tenure. This is because they need the feelings of ownership to make sure that the land will be theirs to work in the foreseeable future, and not unpredictably taken away and reallocate to somebody else. This means farmers' feeling about the land belongs to them will have a positive effect on their decision to participate in watershed management programs. Therefore, in this study, it is hypothesized that land tenure security is positively correlated with the farmers' decision to participate in watershed management programs.

\section{Land redistribution}

Land redistribution aggravates the problem of farmland fragmentation. Therefore, it is hypothesized that land redistribution is negatively correlated with the farmers' decision to participate in watershed management programs.

\section{The slope of the farmland}

It is an indicator of the erosion potential of a farmland. Therefore, farmers' whose farmland is located on steep slopes are more interested to participate in watershed management programs. Thus, it is hypothesized that the slope of a farmland is positively related to farmers' decision to participate in watershed management programs.

\section{Institutional factors}

\section{The frequency of visits by extension workers}

Farmers visited by extension agents is more likely to decide to participate in watershed management programs so that boost their agricultural productivity better than their counterparts. Hence, in this study, it is hypothesized that the frequency of visits by extension workers is positively associated with the farmers' decision to participate in watershed management programs.

\section{Access to credit services}

Credit access reduces liquidity problems that household could face while intending to purchase agricultural inputs, and hence paves the way for the timely application of inputs, thereby increasing the overall productivity and farm income (Mpawenimana 2005). Thus, it is hypothesized that access to credit service is positively correlated with the farmers' decision to participate in watershed management programs.

\section{The productive safety net program}

One of the main goals of the productive safety net program (PSNP) is to ensure that chronically food insecure households can meet their basic food needs while encouraging them to engage in productive activities and build up assets. This is possible, for example, when farmers are able to actively participate in watershed management programs. Hence, in this study, we hypothesized that PSNP is positively associated with the farmers' decision to participate in watershed management programs.

\section{Analyses of factors affecting farmers' participation in watershed management programs}

This section presents the analyses of the binary logistic regression model and explains the socioeconomic, physical, and institutional factors affecting farmers' participation in watershed management programs (Table 3).

\section{Land redistribution}

Frequent land redistribution usually discourages farmers' participation in agricultural investments such as participation in watershed management programs. Corresponding to our expectations, the result of the regression analysis was found to be statistically negative and significant at the $5 \%$ level of significance. This means that the occurrence of frequent land redistribution negatively affects farmers' participation in watershed management programs. This could be attributed to the fact that farmers' perceived the risk of being evicted from their land to have been reduced due to the land redistribution; thereby, they may not be the beneficiary of that particular watershed. This result is in line with the study done by Admassie (2000). He stated that land redistribution has been undertaken with equity concerns. However, it is argued that tenure security is negatively affected by land redistribution. It follows that farmers' propensity to undertake land-improving investments will deteriorate since they expect dispossession of their present holding through the event of future redistribution.

\section{Gender of the household head}

Gender equality makes good sense. One study calculated that agricultural productivity in Sub-Saharan Africa could rise by $20 \%$ if women had equal access to land, seed, and fertilizer (FAO 2009). The statistical analysis of this study showed that $80 \%$ of the sample households are male-headed and $20 \%$ are female-headed. Unlike to our expectation, the binary logistic regression analysis of 
Table 3 The statistical results of the regression analysis

\begin{tabular}{|c|c|c|c|c|c|c|c|c|}
\hline & \multirow[t]{2}{*}{ B } & \multirow[t]{2}{*}{ S.E. } & \multirow[t]{2}{*}{ Wald } & \multirow[t]{2}{*}{$d f$} & \multirow[t]{2}{*}{ Sig. } & \multirow[t]{2}{*}{$\operatorname{Exp}(B)$} & \multicolumn{2}{|c|}{ 95\% C.I. for EXP(B) } \\
\hline & & & & & & & Lower & Upper \\
\hline Off-farm income & 1.159 & .650 & 3.182 & 1 & .074 & 3.187 & .892 & 11.386 \\
\hline Livestock holding & .265 & .142 & 3.468 & 1 & .063 & 1.303 & .986 & 1.722 \\
\hline Land redistribution & -1.179 & .589 & 4.003 & 1 & $.045^{*}$ & .308 & .097 & .976 \\
\hline Land tenure security & -.878 & .507 & 3.002 & 1 & .083 & .416 & .154 & 1.122 \\
\hline Educational status & -.861 & .473 & 3.318 & 1 & .069 & .423 & .167 & 1.068 \\
\hline Gender & -2.597 & 1.099 & 5.581 & 1 & $.018^{*}$ & .075 & .009 & .643 \\
\hline Agricultural labor force & -582 & .296 & 3.875 & 1 & $.049^{*}$ & .559 & .313 & .997 \\
\hline Access to credit service & -.877 & .592 & 2.192 & 1 & .139 & .416 & .130 & 1.328 \\
\hline Agricultural extension service & -.630 & .173 & 13.268 & 1 & $.000^{* *}$ & .533 & .380 & .748 \\
\hline Productive safety net program & .972 & .675 & 2.077 & 1 & .150 & 2.644 & .705 & 9.919 \\
\hline Farm size & 1.759 & .784 & 5.030 & 1 & $.025^{*}$ & 5.805 & 1.248 & 26.993 \\
\hline Slope & -1.572 & .478 & 10.810 & 1 & $.001^{* *}$ & .208 & .081 & .530 \\
\hline Constant & 5.626 & 3.047 & 3.408 & 1 & .065 & 277.604 & & \\
\hline
\end{tabular}

this variable was found to be statistically negative and significant at the $5 \%$ level of confidence.

\section{Agricultural labor force}

The statistical analysis of the study showed that the mean agricultural labor force of the sample households is 2.2 persons ranging from 1 to 5 with a standard deviation of 0.95. Contrary to our expectations, the result of the regression analysis revealed that the agricultural labor force is found to be statistically negative and significant at the $5 \%$ level of confidence. This means as the number of the agricultural labor force of a household increases, the farmer's decision to participate in watershed management programs decreases. This could be because of the farmer's negative attitude towards the program and/or lack of information about the long-term benefits of the program.

\section{Agricultural extension services}

Agricultural extension services in Ethiopia are carried out at the kebele level using extension officers. There are three extension officers, also known as development agents (DAs) in each kebele specializing in plant sciences/crop protection, natural resources management, and livestock production. In this study, agricultural extension services are intended to educate farmers and assist in resolving their agriculture-related problems, thereby motivating them to decide to participate in watershed management programs hence increased production. Contrary to our expectations, the regression analysis of this variable revealed that frequency of agricultural extension service is found to be statistically negative and significant at the $1 \%$ level of confidence. This means as the frequency of agricultural extension services received by a farmer increases, his/her decision to participate in watershed management program decreases. This could be explained by the fact that the quality of services received may be affected by the inadequate number of agricultural extension workers and inadequacy of working facilities such as lack of transport service. This result is consistent with the study done in Ethiopia by Amsalu (2015). He stated that experiences with technology adoption in Ethiopia indicate that farmers are either reluctant to uptake external recommendations or take some more time to comprehend and implement. However, a study done by Miheretu and Yimer (2017) in the Northern highlands of Ethiopia reported that access to extension service positively and significantly affects the adoption of stone bund and chemical fertilizer. Hence, DAs need to spend more time with farmers to properly inform and persuade them about the importance of technologies and assist them to enhance land productivity, which is practically challenged by the disproportionately large number of farmers. Apart from their main duties, the DAs are expected to engage in additional activities such as distributing fertilizer, the collection of credit and taxes, and other government activities that do not typically fall under the mandate of extension (Davis et al. 2010).

\section{Farm size}

Land is an important means of agricultural production in rural areas. It plays a central role in producing crops and rearing livestock. In this study, having large farm size is associated with producing and supplying more farm produce for the market. The survey result showed that $91.6 \%$ of the sample households have less than 1 ha 
of farmlands. Only 8.4\% households have farmlands ranging from 1 to 2 ha. Corresponding to our expectations, the result of the regression analysis revealed that farm size is found to be statistically positive and significant at the $5 \%$ level of confidence. This suggests that as the farm size of a household head increases, his/her decision to participate in watershed management program increases. This could be explained by the fact that farmers having large farm size are more optimistic in getting better production than their counterparts. This result is consistent with the study done in Ethiopia by Bekele and Drake (2003). They reported that existence of conservation measures is positively related to landholding size. This result is also in line with the findings of Arun et al. (2012). They reported that the participation of farmers' increases as farm size increases.

\section{The slope of a farmland}

Slope of a farmland affects the rate and amount of soil loss from fields. This forces farmers to control or mitigate the impact of erosion on fields that are situated on steep slopes and hence slope influences the decision of farmers to participate in watershed management programs. Contrary to our expectation, the regression analysis result of this variable is found to be statistically negative and significant at the $1 \%$ level of confidence. This may be due to farmers' lack of knowledge about the effects of slope for soil nutrient losses from their farmlands. This result is consistent with the study done in Ethiopia by Alemu (1999). He found that statistically significant and negative relationship between slope and farmers participation in conservation investment. He argued the returns from investment on steeply sloped plots might be low, hence less adoption on such plots. A study conducted by Miheretu and Yimer (2017) in the Northern highlands of Ethiopia also indicated that the slope of the plot does not significantly influence the adoption of chemical fertilizers. But Wossen et al. (2015) reported that the slope of the plot affects the adoption decision of farmers on land management practices positively and significantly.

\section{Correlation analyses for continuous independent variables of the study}

Pearson correlation analysis was conducted in order to know the association between independent variables and farmers' participation in watershed management programs. Consequently, the analysis revealed that farmers' perceptions about watershed management programs and government support given to watershed management programs have a significant and positive association with the farmers' decision to participate in watershed management programs. Farmers' perception has a strong positive relationship $(r=0.612, P=0.000)$ with the farmers' decision to participate in the watershed management programs followed by government support of the watershed management programs $(r=0.163, P=0$. 017), while the slope of the farmland and the gender of the household head have shown significant and negative associations (Table 4).

\section{Statistical summary for discrete variables of the study}

Two out of seven discrete variables included in the analysis found to be significant in explaining variations in affecting the farmers' decision to participate in watershed management programs (Table 5). These variables are the gender of the household head and land tenure security.

\section{Educational status of the household head}

The educational status of the sample households revealed that $27.4 \%$ of the sample households are literate. Among literate households, 25 and $38.5 \%$ were found to be participants and non-participants of watershed management program respectively. The chi-square result $\left(X^{2}=2.906\right)$ of this variable is statistically insignificant at the $95 \%$ level of significance. Hence, there is no correlation between the educational status of the household heads and their participation in watershed management programs. This may be because of the bottom-up approach of the program which enables farmers' to discuss thoroughly the importance and long-term benefits of the watershed management programs.

\section{Gender of the household head}

Based on the survey result of this study, there are more male-headed sample households (80\%) than female-headed households (20\%). The analysis of chi-square indicates that 76.1 and $23.9 \%$ of male-headed and female-headed sample households were participants of watershed management program respectively. The chi-square result $\left(X^{2}=9.052\right)$ of this variable is statistically significant at the $95 \%$ level of significance. This means there is a significant association between gender of a household head and his/her decision to

Table 4 Correlation between continuous independent variables and farmers' participation

\begin{tabular}{lll}
\hline Variables & $(r)$ & $(P)(2$-tailed) \\
\hline Livestock ownership & .067 & 0.325 \\
Slope & $-.168^{\mathrm{a}}$ & .014 \\
Gender & $-.205^{\mathrm{b}}$ & .002 \\
Farmland size & .119 & .081 \\
Family size & .021 & .756 \\
Off-farm income & -.029 & .673 \\
Perception & $.6121^{\mathrm{b}}$ & .000 \\
Government support & $.163^{\mathrm{a}}$ & .017 \\
\hline
\end{tabular}

${ }^{a}$ Correlation is significant at the 0.05 level (2-tailed)

${ }^{\mathrm{b}}$ Correlation is significant at the 0.01 level (2-tailed) 
Table 5 Descriptive summary of discrete variables

\begin{tabular}{|c|c|c|c|c|c|c|}
\hline \multirow[t]{2}{*}{ Variables } & \multicolumn{2}{|c|}{ Participant $(N=176)$} & \multicolumn{2}{|c|}{ Non-participant $(N=39)$} & \multirow[t]{2}{*}{ Chi-square value } & \multirow[t]{2}{*}{ Asymp. sig (2-sided) } \\
\hline & Number & $\%$ & Number & $\%$ & & \\
\hline \multicolumn{7}{|c|}{ Educational status of the $\mathrm{HH}$ head } \\
\hline Literate & 44 & 25 & 15 & 38.5 & 2.906 & 0.088 \\
\hline Illiterate & 132 & 75 & 24 & 61.5 & & \\
\hline \multicolumn{7}{|c|}{ Gender of the $\mathrm{HH}$ head } \\
\hline Male & 134 & 76.1 & 38 & 97.4 & $9.052^{*}$ & 0.003 \\
\hline Female & 42 & 23.9 & 1 & 2.6 & & \\
\hline \multicolumn{7}{|c|}{ Access to PSNP } \\
\hline Yes & 43 & 24.4 & 4 & 10.3 & 3.756 & 0.053 \\
\hline No & 133 & 75.6 & 35 & 89.7 & & \\
\hline \multicolumn{7}{|c|}{ Access to credit services } \\
\hline Yes & 133 & 75.6 & 33 & 84.6 & 1.485 & 0.223 \\
\hline No & 43 & 24.4 & 6 & 15.4 & & \\
\hline \multicolumn{7}{|c|}{ Land tenure security } \\
\hline Yes & 55 & 31.2 & 22 & 56.4 & $8.792^{*}$ & 0.003 \\
\hline No & 121 & 68.8 & 17 & 43.6 & & \\
\hline \multicolumn{7}{|c|}{ Access to off-farm income } \\
\hline Yes & 31 & 17.6 & 8 & 20.5 & 0.181 & 0.671 \\
\hline No & 145 & 82.4 & 31 & 79.5 & & \\
\hline \multicolumn{7}{|c|}{ Stakeholder support } \\
\hline Yes & 67 & 38 & 16 & 41 & 0.118 & 0.731 \\
\hline No & 109 & 62 & 23 & 59 & & \\
\hline
\end{tabular}

participate in watershed management programs. Particularly, women are the most affected by environmental hardships; for instance, they need to walk long hours to fetch increasingly scarce water, firewood, and animal dung in addition to attending livestock. Their participation in watershed development planning, implementation, and management is crucial to ensure that they equally benefit from the various measures (MoARD (Ministry of Agriculture and Rural Development) 2005).

\section{Access to productive safety net program}

The survey result of this variable showed that 24.4 and 75 . $6 \%$ of participants of watershed management programs have and do not have access to the PSNP respectively. While 10.3 and $89.7 \%$ of non-participants of watershed management programs have access and have no access to the PSNP respectively. The chi-square result $\left(X^{2}=3.756\right)$ of access to PSNP is statistically insignificant at the $95 \%$ level of significance. Therefore, there is no association between access to the PSNP and farmers' decision to participate in watershed management programs.

\section{Access to credit services}

The analysis of access to credit services received by farmers showed that 75.6 and $24.4 \%$ of the farmers have and do not have access to credit services respectively. The chi-square result $\left(X^{2}=1.485\right)$ of access to credit services is statistically insignificant at the $95 \%$ level of significance. Therefore, there is no relation between access to credit services and farmers' decision to participate in watershed management programs. This could be because of farmers' fear about their inability to pay back the credit within the prescribed period of time, which could lead to punishment.

\section{Land tenure security}

Farm households' investment in practices that enhance the long-term viability of agricultural production hinges significantly on the expectations regarding the length of time over which the farmers might enjoy the benefits. These expectations depend on the sense of tenure insecurity (whether through ownership of disputes, eviction or expropriation by the government). With titling (ownership officially documented and verified via land certificates), the land holder's sense of tenure security will be enhanced and, therefore, boost incentives to invest in such practices that enhance long-term sustainability of agricultural production (such as land improvements, conservation practices and adoption of new technology) which ultimately may increase farm productivity (Gebremedhin and Swinton 2003; Holden et al. 
2009). The statistical analysis of this study revealed that 35 . $8 \%$ of the sample households have thought about the risk of loss of their farmlands due to lack of land tenure security. The chi-square result $\left(X^{2}=8.792\right)$ of this variable is statistically significant at the $95 \%$ level of significance. Therefore, there is a significant association between land tenure security and farmers' decision to participate in watershed management programs. This means if farmers feel a sense of tenure security, their interest to participate in watershed management program increases.

\section{Stakeholder support}

Watershed management is dedicated to solving watershed problems on a sustainable basis. Hence, for successful implementation of solutions to the physical and economic problems of a watershed, a broad, representative array of stakeholders should be involved (Grigg 1998; Said et al. 2006). Getting stakeholders involved and utilizing their input in a watershed management program is a key point. Therefore, $38.6 \%$ of the sample households stated that stakeholders provide the necessary support for watershed management programs. However, the remaining $61.4 \%$ of them stated that stakeholders do not provide the necessary support. The chi-square result $\left(X^{2}=0.118\right)$ of this variable is statistically insignificant at the $95 \%$ level of significance. Therefore, there is no correlation between stakeholders support and farmers' decision to participate in watershed management programs.

\section{Farmers' reasons for not participating in the watershed management programs}

The survey result of the study showed that $81.9 \%$ of the respondents voluntarily participated in the watershed management programs, while the remaining $18.1 \%$ did not voluntarily participate. As shown in Fig. 3, farmers gave various reasons for not participating in the watershed management programs. These include lack of awareness (7.7\%), lack of incentives (59\%), lack of good governance $(20.5 \%)$ and time-consuming nature of the program $(12.8 \%)$. The key informant interview was also conducted to get additional information. Hence, 12 key informants, who had deep knowledge and experience on the programs, were interviewed. They reported that the engagement of farmers in off-farm activities, having a negative attitude towards the program, lack of knowledge, and demanding short-term benefits from the program are the main reasons for farmers not participating in the program. Therefore, it is better to raise the awareness of farmers about the long-term benefits of watershed programs and design a strategy to diversify their livelihoods. The livelihood diversification strategy may include animal fattening, production of cash crops using small-scale irrigation and water harvesting.

\section{Focus group discussions and informant interview results}

Focus group discussions and key informant interviews are effective ways for understanding the local conception of community in the area. Participants were selected based on their specific characteristics like gender, farm experience, age, job, and position. Three FGDs were formed: one focus group in each of the upper-highland, highland, and midlands ago-climatic zones. Each group of 8 persons, both men and women, was included in the FGDs. Key informant interviews were also conducted to complement data obtained from other sources. The key informants include kebele administrators, elders, and PSNP beneficiary and non-beneficiary farmers. Accordingly, 12 persons participated in the interview sessions. Key topics covered during the key informant interviews and FGDs include the implementation of physical and biological SWC measures, the provision of inputs, administration procedures, the provision of agricultural extension services, benefits of PSNP, and opinions about the role of the watershed management program as an agricultural water management solution.

Consequently, the survey results obtained through both FGDs and key informant interviews identified several factors that affect farmers' participation in watershed management programs. These include poverty, lack of good governance, shortage of farmland, drought, lack of incentives, and the shortage of rainfall. More than $90 \%$ of the interviewed farmers reported that farmlands are becoming scarcer in the study area due to land fragmentation. Such a fragmentation is attributed to the rapid population growth of the area. On the other hand, some FGD participants emphasized the problem of lack of good governance. They reported that there are some administrative bodies that compel farmers to participate in the watershed management programs without their agreement. Furthermore, they indicated the problem of punishment. This means when they are absent during the watershed development program, the coordinators of the program punish them without considering their reasons for absenteeism. The kind of punishment is usually in terms of cash and social outcast system. Therefore, instead of taking such measures, it is advisable to teach them and raise their awareness about the significance of the program through training, workshops, and seminars.

\section{Conclusions}

This study investigated factors affecting farmers' participation in watershed management programs in the Teleyayen sub-watershed of Ethiopia. The regression analysis results of the study indicated that among the 12 hypothesized explanatory variables included in the model, 6 were found to have a significant influence on the farmers' decision to participate in watershed management programs. In this regard, the results confirmed that variables like land redistribution, 


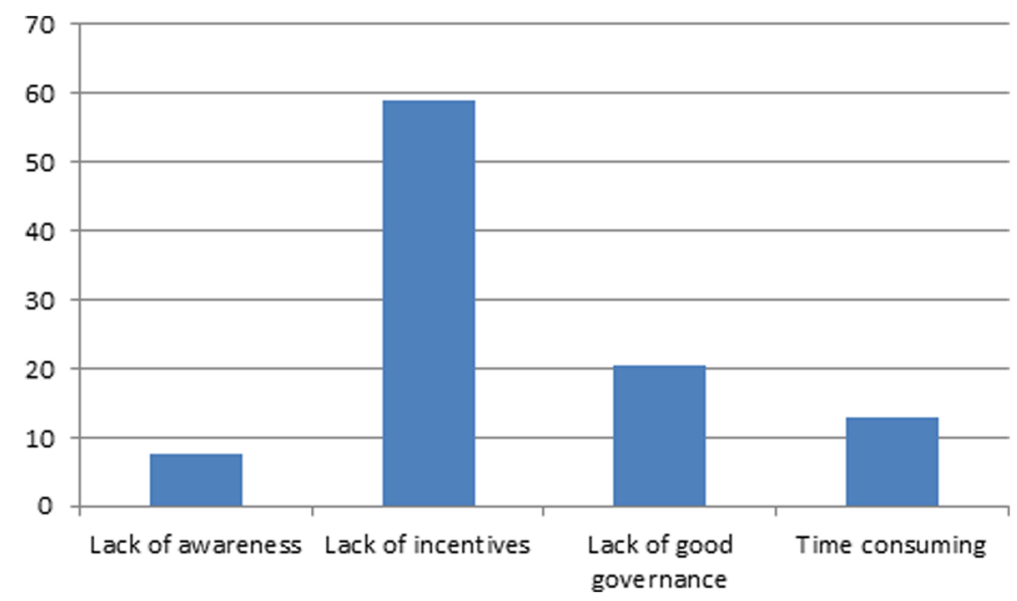

Fig. 3 Farmers' reasons for not participating in watershed management programs in percent

gender, agricultural labor force, extension service, farm size, and slope were key factors affecting the farmers' decision to participate in the watershed management programs. Particularly, land redistribution, gender, agricultural labor force, extension service, and slope indicated a negative influence. This indicates that in Ethiopia, the problem of watershed degradation is aggravated both by the natural and man-made reasons. For example, rapid population growth leads to increased demand for farmland and forest resource for firewood and home construction. Therefore, continuous watershed assessment strategies should be introduced because continuous and planned watershed assessments provide initial estimates of where conservation investments would best address the concerns of landowners, conservation districts, and other community organizations and stakeholders. These assessments help landowners and local leaders set priorities and determine the best actions to achieve their goals. These assessments are conducted by watershed planning teams traveling through each watershed, meeting with landowners and conservation groups, inventorying agricultural areas, identifying conservation opportunities and current levels of resource management, and estimating impacts of these opportunities on the local priority resource concerns. Farm size of a household was the only variable that exerts a positive impact on farmers' participation. Furthermore, the study examined the role of discrete variables in explaining variations of variables in affecting the farmers' decision to participate in the program. Thus, two variables found to be significant in explaining variations. These variables were the gender of the household head and land tenure security. Accordingly, the chi-square result $\left(X^{2}=9.052\right)$ of gender was found to be statistically significant at the $95 \%$ level of significance. This means there is a significant association between gender of household heads and their decisions to participate in the program. Similarly, the chi-square result $\left(X^{2}=8.792\right)$ of land tenure security was found to be statistically significant at the $95 \%$ level of significance. This implies that there is a significant association between land tenure security and the farmer's decision to participate in watershed management programs.

Focus group discussions and key informant interviews were also conducted to complement data obtained from other sources. Consequently, the survey results obtained through both FGDs and key informant interviews identified several factors that affect farmers' participation in watershed management programs. These include poverty, lack of good governance, shortage of farmland, drought, lack of incentives and the shortage of rainfall. More than $90 \%$ of the interviewed farmers' stated that farmlands are becoming scarcer in the study area due to land fragmentation. Such a fragmentation is attributed to the rapid population growth of the area. On the other hand, some FGD participants emphasized the problem of lack of good governance. They reported that there are some administrative bodies that compel farmers to participate in the watershed management programs. In this regard, they indicated the problem of punishment. This means when they are absent during the watershed development program day, the coordinators of the program punish them without considering their reasons for absenteeism. The kind of punishment is usually in terms of cash and social outcast system. Therefore, instead of taking such measures it is advisable to teach them and raise their awareness about the significance of the watershed management programs through training, workshops, and seminars.

The survey result of the study showed that $81.9 \%$ of the respondents voluntarily participated, while $18.1 \%$ did not voluntarily participate in the watershed management programs. Respondents gave various reasons for not participating in the program. These include lack of awareness (7.7\%), lack of incentives (59\%), lack of good governance $(20.5 \%)$, and time-consuming nature of the program (12.8\%). The key informant interview was also 
conducted to get additional information. As a result, they reported that the engagement of farmers' in offfarm activities, having a negative attitude towards the program, lack of knowledge, and demanding short-term benefits from the program are the main reasons. Therefore, it is better to raise the awareness of farmers' about the long-term benefits of the watershed programs and try to design a strategy to diversify their livelihoods. The livelihood diversification may include animal fattening, production of cash crops using small-scale irrigation, and water harvesting.

In conclusion, this study discovered that farmers' participation in watershed management program is highly affected by a number of factors and have a positive relationship with their level of participation. However, a number of variables also have a negative relationship with the farmers' level of participation in the watershed. This indicates the overall respondents' knowledge and interest towards the watershed management program was relatively low because of the factors that have a negative impact on their participation. Hence, more effort is needed for raising farmers' awareness through delivering information on the importance of watershed management programs. The study also recommends that similar research should be conducted in other watersheds to validate the findings of this study and a more in-depth study should be done by incorporating other variables such as farmers past experiences and farmers' trust to government policy, to further enhance the identification of factors that affect farmers' participation in watershed management programs to improve the prediction of the level of their participation.

\section{Endnotes}

${ }^{1}$ Watershed management is the integrated use of land, vegetation and water in a geographically discrete drainage area for the benefit of its residents, with the objective of protecting or conserving the hydrologic services that the watershed provides and of reducing or avoiding negative downstream or groundwater impacts (Darghouth et al. 2008).

${ }^{2}$ kebele is the smallest administrative unit of Ethiopia.

\section{Abbreviations}

DA: Development agent; FGD: Focus group discussion; PSNP: Productive safety net program; SLM: Sustainable land management; SWC: Soil and water conservation; WDP: Watershed Development Program

\section{Acknowledgements}

The authors would like to thank the International Foundation for Science (IFS) for providing financial support to the first author. We also thank farmers and development agent workers who took part in the survey.

\section{Funding}

This study was financially supported by the International Foundation for Science (IFS). Hence, it has played a great role in the design and collection of data for the study.

\section{Availability of data and materials}

The authors declare that the data and materials presented in this manuscript can be made publicly available by Springer Open as per the editorial policy.

\section{Authors' contributions}

AAA has contributed in designing the study, collection of data, and analysis and interpretation of data and he wrote the manuscript. Dr. KNS also contributed in reviewing and writing the draft manuscript as well as editing the manuscript. Both authors read and approved the final manuscript.

\section{Authors' information}

AAA: He is a lecturer working at the Department of Geography and Environmental Studies, Wollo University, Ethiopia. He attended his Bachelor and Master's degree in Geography and Environmental Studies from Bahir Dar University of Ethiopia. Currently, he is a Ph.D student at Addis Ababa University, Ethiopia. His area of research is focused on land management, soil and water conservation, food security, and watershed management. KNS: He is an associate professor and lecturer at the Department of Geography and Environmental Studies, Addis Ababa University, Ethiopia. His area of specialization in the field of geography is physical geography and quantitative methods. He has been engaged in research and teaching at the University level for more than 40 years. Currently, he is advising two Ph.D students and six Master program students. Moreover, he has served as an internal Ph.D examiner. As a researcher, he has carried out several researches in the area of my specialization, which focused on aspects of morphommetry, quantitative analysis of landforms, and settlement distributions in many parts of India and Ethiopia.

\section{Competing interests}

The authors declare that they have no competing interests.

\section{Publisher's Note}

Springer Nature remains neutral with regard to jurisdictional claims in published maps and institutional affiliations.

\section{Author details}

'Department of Geography and Environmental Studies, Wollo University, P.O. Box 1145, Dessie, Ethiopia. ${ }^{2}$ Department of Geography and Environmental Studies, Addis Ababa University, P.O. Box 1176, Addis Ababa, Ethiopia.

Received: 3 January 2018 Accepted: 16 April 2018

Published online: 30 April 2018

\section{References}

Abedini KH (2001) Analysis of factors influencing animal husbandmen' participation in range management plans in Damavand region Lar Basin. For Range Qual 53:44-52

Aboueieh F (2001) Correlation of some factors influencing attraction of animal husbandmen' participation in range conservation and rehabilitation in Semnan Province, M.Sc. Thesis, Science and Research Unit. Islamic Azad University, Tehran

Admassie Y (2000) Twenty years to nowhere: property rights, land management, and conservation in Ethiopia. the Red Sea Press, Inc, Asmera;Lawrenceville

Ahmadvand M, Karami E, Iman MT (2011) Modeling the determinants of the social impacts of agricultural development projects. Environ Impact Assess Rev 31(1):8-16. https://doi.org/10.1016/j.eiar.2010.06.004

Alemu T (1999) Land tenure and soil conservation: Evidence from Ethiopia. A Ph. D. Thesis. University of Goteborg: Goteborg

Amsalu A (2015) Institutional context for soil resources management in Ethiopia: a review report. September 2015, Addis Ababa, Ethiopia

Angurana AK (2003) Gender orientation to watershed development. Jharkhand J Dev Manag Stud 1(3):393-395

Arun G, Singh DR, Kumar S, Kumar A (2012) Canal irrigation management through water users associations and its impact on efficiency, equity and reliability in water use in Tamil Nadu. Agric Econ Res Rev 25:409-419

ATA (Ethiopian Agricultural Transformation Agency) (2013) Annual report 2013/ 2014: transforming agriculture in Ethiopia. Ethiopian Agricultural Transformation Agency (ATA), Addis Ababa

Azizi KT, Zamani GH (2009) Farmer participation in irrigation management: the case of Doroodzan dam irrigation network, Iran. J Agric Water Manag 96(5): $859-865$ 
Badege B (2001) "Deforestation and land degradation on the Ethiopian highlands: a strategy for physical recovery" (2001). International Conference on African Development Archives. Paper 2. Retrieved on July 10, 2016, from https://scholarworks.wmich.edu/cgi/viewcontent.cgi?article=1002\&context= africancenter_icad_archive. Accessed 10 July 2016

Bekele W, Drake L (2003) Soil and water conservation decision behavior of subsistence farmers in the eastern highlands of Ethiopia: a case study of Hunde-Lafto area. Ecol Econ 46(3):437-451

Bewket W (2003) Land degradation and farmers' acceptance and adoption of conservation technologies in the Digil Watershed, northwestern highlands of Ethiopia. Social Science Research Report series-no 29. OSSERA, Addis Ababa

Darghouth S, Ward C, Gambarelli G, Styger C, Roux J (2008) Watershed management approaches, policies, and operations: lessons for scaling up water sector board discussion papaer series, paper no.11. The World Bank, Washington, D.C

Davis K, Swanson B, Amudavi D, Ayalew DM, Flohrs A, Riese J (2010) In depth assessment of the public agricultural extension system of Ethiopia and recommendations for improvement. IFPRI discussion paper 01041. International Food Policy Research Institute, Washington, D.C.

Diao X (2010) Economic importance of agriculture for sustainable development and poverty reduction: the case study of Ethiopia. Paper presented at the OECD global forum on agriculture: policies for agricultural development, poverty reduction and food security, November 29-30, 2010, Organization for Economic Co-operation and Development (OECD) Headquarters, Paris

Dolisca F, Douglas RC, Joshua MM, Dennis AS, Curtis MJ (2006) Factors influencing farmers' participation in forestry management programs: a case study from Haiti. Forest Ecol Manag 236:324-331. https://doi.org/ 10.1016/j.foreco.2006.09.017

Ebrahim PM (2000) Status of participation action and factors influencing it in watershed management. Collection of articles of first convention of natural resources, participation and development. Forests, Range and Watershed Management Organization of Iran, Tehran, pp 173-199

Elias E (2002) Farmers' perceptions of soil fertility change and management. SOS Sahel Ethiopia; and Institute for Sustainable Development, Addis Ababa

Faham E, Hosseini SM, Darvish AK (2008) Analysis of factors influencing rural people's participation in National Action Plan for Sustainable Management of Land and Water Resources in Hable-Rud Basin, Iran. Am J Agric Biol Sci 3(2): 457-461

FAO (1986) Ethiopian highlands reclamation study. Report prepared for the Government of Ethiopia by the Food and Agriculture Organization of the United Nations, Ethiopia final report, vol 1 Retrieved on December 6, 2016, from http://www.fao.org/docrep/field/009/ar863e/ar863e.pdf. Accessed 6 Dec 2016

FAO (2009) FAO's programme for gender equality in agriculture and rural development. Division, FAO, Rome

Gebremedhin B, Swinton SM (2003) Investment in soil conservation in northern Ethiopia: the role of land tenure security and public programs. Agric Econ 29(1):69-84

Georgis K, Dejene A, Malo M (2010) Agricultural based livelihood systems in drylands in the context of climate change: inventory of adaptation practices and technologies of Ethiopia. Environment and Natural Resources Management working paper 38. Food and Agriculture Organization of the United Nations (FAO), Rome

German L, Mansoor H, Alemu G, Mazengia W, Amede T, Stroud A (2007) Participatory integrated watershed management: evolution of concepts and methods in an eco-regional program of the eastern African highlands. Agric Syst 94(2):189-204

Grigg NS (1998) Coordination: the key to integrated water management. Water resources. Update, special issue no. 111. Universities Council on Water Resources, Carbondale

Haregeweyn N, Poesen J, Nyssen J, De Wit J, Mitiku H, Govers G, Deckers $S$ (2005) Reservoirs in Tigray (Northern Ethiopia): characteristics and sediment deposition problems. Land Degrad Dev 17(2):211-230. https://doi.org/10.1002/ldr.698

Heathcote IW (1998) Integrated watershed management: principles and practice. Wiley, New York

Holden ST, Deininger K, Ghebru H (2009) Impacts of low-cost land certification on investment and productivity. Am J Agric Econ 91(2):359373. https://doi.org/10.1111/j.1467-8276.2008.01241.x

Karegar A, Abedi Sarvestani A (2001) Contexts of public participation in natural resources plans (case study). Collection of articles of first convention of natural resources, participation and development. Forests, Range and Watershed Management Organization of Iran, Tehran, pp 371-401

Khalighi N, Ghasemi T (2004) Analysis of effect of socio-economic problems on level of stock breeders' participation in range management plans in north Golestan Province, Iran. J Agric, Nat Resour Sci 11(1):181-190

Lemenih M (2004) Effects of land use changes on soil quality and native flora degradation and restoration in the highlands of Ethiopia: implications for sustainable land management. Ph.D Thesis. Swedish University of Agricultural Sciences, Uppsala

McMillan MB, Hoban TJ, Clifford WB, Brant MR (1996) Social and demographic influences of environmental attitudes. South Rural Sociol 13(1):89-107

Meinzen-Dick R, DiGregorio M, McCarthy N (2004) Studying collective action in rural development. Agric Syst 82(2004):197-214

Melaku B (2003) Forest property rights, the role of the state, and institutional exigency: the Ethiopian experience. Ph.D Thesis, Swedish University of Agricultural Sciences. Sveriges lantbruksuniv., Acta Universitatis agriculturae Sueciae. Agraria, Uppsala, pp 1401-6249 409. ISBN 91-576-6429-3

Miheretu BA, Yimer AA (2017) Land use/land cover changes and their environmental implications in the Gelana sub-watershed of northern highlands of Ethiopia. Environ Syst Res 6(7):1-12. https://doi.org/10.1186/s40068-017-0084-7

MoARD (Ministry of Agriculture and Rural Development) (2005) Community based participatory watershed development: a guideline. Part 1, First edn. Ministry of Agriculture and Rural Development, Addis Ababa

MoFED (2010) Growth and transformation plan 2010/11-2014/15. Volume I: main text. Ministry of Finance and Economic Development (MoFED), Federal Democratic Republic of Ethiopia, Addis Ababa

Motevalli $H$ (2002) Analysis of factors influencing attraction of villagers' participation in desertification plans in Semnan Province. For Range Qual 56:50-60

MoWR (1993) Improvement of the resource-population sustainability balance. Water Resources Development, MoWR, Addis Ababa

Mpawenimana J (2005) Analysis of socioeconomic factors affecting the production of Bananas in Rwanda: A case study of Kanama district. University of Nairobi: Nairobi

Osman M, Sauerborn P (2001) Soil and water conservation in Ethiopia: experiences and lessons. J Soils Sediments 1(2):117-123

Rodeco (2002) Assessment and monitoring of erosion and sedimentation problems in Ethiopia - final report. Rodeco Consulting $\mathrm{GmbH}$, Hydrology Studies Department, Ministry of Water Resources, Addis Ababa

Said A, Sehlke G, Stevens DK, Glover T, Sorensen D, Walker W, Hardy T (2006) Exploring an innovative watershed management approach: from feasibility to sustainability. Energy 31(13):2373-2386. https://doi.org/10.1016/j.energy.2006.02.002

Seeley J, Batra M, Sarin M (2000) Women's participation in watershed development in India. Gatekeeper series no. 92. International Institute for Environment and Development, London, p 20

Shahidi M (1998) Analysis of factors influencing participation in under pressure irrigation from view point of farmers in northwest province of Iran. M.Sc. Thesis, Tehran University: Tehran

Sharma C, Sisodia SS (2008) People's participation in watershed development programme: case study of Rajasthan. Indian Res J Ext Educ 8(1):71-72

Taffa T (2009) Characteristics of property units in Ethiopia, the case of two pilot projects in Amhara National Regional State. Nord J Survey Real Estate Res 6(2):7-24. https://doi.org/10.1017/ S0376892900007955

Tamene $L$ (2005) Catchment erosion - reservoir siltation: processes in the highlands of Ethiopia. Ph.D Thesis. Zentrum für Entwicklungsforschung (Center for Development Research) (ZEF), University of Bonn, Bonn

Wossen T, Berger T, Di Falco S (2015) Social capital, risk preference and adoption of improved farm land management practices in Ethiopia. Agric Econ 46:81-97

Yemane T (1967) Statistics, An introductory Analysis. 2nd ed., New York: Harper and Row

Zarafshani K, Alibaygi AH, Afshar N (2008) The utility of discriminant analysis for prediction of Farmers' intentions to participation in farmer-managed irrigation Systems in Iran. J Appl Sci 8:697-701 